\title{
Amostra de filmagem e análise da pragmática na síndrome de Down*****
}

\author{
Filmed sample size and pragmatic analysis in Down syndrome
}

\author{
Eliza Porto* \\ Suelly Cecilia Olivian Limongi** \\ Irlaine Guedes dos Santos*** \\ Fernanda Dreux Miranda Fernandes****
}

*Fonoaudióloga. Especialização em Fonoaudiologia nos Distúrbios Psiquiátricos da Infância pela Faculdade de Medicina da Universidade de São Paulo. Endereço para correspondência: Rua Cipotânea, 51 - Cidade Universitária São Paulo - SP - CEP 05360-160 (portoeliza@yahoo.com.br).

**Fonoaudióloga. Livre-Docente. Professor Doutor Associado do Departamento de Fisioterapia, Fonoaudiologia e Terapia Ocupacional da Faculdade de Medicina da Universidade de São Paulo.

***Acadêmica em Fonoaudiologia pela Faculdade de Medicina da Universidade de São Paulo.

*****Fonoaudióloga. Professor Associado do Departamento de Fisioterapia, Fonoaudiologia e Terapia Ocupacional da Faculdade de Medicina da Universidade de São Paulo.

*****Pesquisa Realizada na Faculdade de Medicina da Universidade de São Paulo.

Artigo de Pesquisa

Artigo Submetido a Avaliação por Pares

Conflito de Interesse: não

\begin{abstract}
Background: assessing language development is a complex task that requires practical and theoretical knowledge about the investigated issues. It is also important to take into account data gathering and analysis methodology, in order to achieve consistent and reliable results that mirror the subject's reality. Aim: considering the purpose of obtaining the maximum data in minimum time, without jeopardizing their quality and effectiveness, our aim is to identify the better sample's size and moment of videotaped interaction to study the pragmatic abilities of children with Down syndrome. Method: the communicative profile of 25 children with Down syndrome aged between 2 and 7 years were determined as proposed by Fernandes (2004). Data obtained through samples of 15 and 30 minutes were analyzed and compared. The situation analyzed provided interaction between the child and a speech-and language-therapist in play situations. To determine the statistical significance of data the tests Friedman, Wilcoxon and confidence interval were applied with a significance level of $0.05(5 \%)$. Conclusion: there were no significant differences related to the obtained samples with different videotaped duration for pragmatic analysis of the communication of children with Down syndrome.
\end{abstract}

Key Words: Language; Down Syndrome; Communication; Language Therapy.

\section{Resumo}

Tema: avaliar o desenvolvimento da linguagem é uma tarefa complexa que exige conhecimentos teóricos e práticos a respeito dos aspectos que se deseja investigar, considerando-se a metodologia a ser utilizada na coleta e na análise dos dados, a fim de serem obtidos resultados consistentes e confiáveis, que reflitam a realidade do sujeito. Objetivo: considerando-se a obtenção do maior número de dados em menor tempo possível, sem prejuízo da qualidade e efetividade dos dados obtidos, nosso objetivo é identificar o momento e o tempo de filmagem de situação de interação, mais adequados para realizar a análise da pragmática de crianças com síndrome de Down. Método: foi traçado o perfil comunicativo de 25 crianças com síndrome de Down, de dois a sete anos de idade, utilizando-se a proposta de avaliação elaborada por Fernandes (2004), comparando-se os dados obtidos na análise de amostras de 30 e 15 minutos de filmagem. A situação analisada foi a de interação entre terapeuta e criança em brincadeira lúdica. Para verificar a significância dos dados, foi realizada análise estatística, utilizando os testes de Friedman e Wilcoxon e a técnica de Intervalo de Confiança, com nível de significância igual a $0,05(5 \%)$. Conclusão: não foram encontradas diferenças significativas relacionadas às amostras obtidas com diferentes durações de filmagem para a análise da pragmática da comunicação de crianças com síndrome de Down.

Palavras-Chave: Linguagem; Síndrome de Down; Comunicação; Terapia de Linguagem.

Recebido em 11.05.2006.

Revisado em 28.02.2007; 29.05.2007.

Aceito para Publicação em 29.05.2007.

Referenciar este material como:

PORTO, E.; LIMONGI, S. C. O.; SANTOS, I. G.; FERNANDES, F. D. M. Filmed sample size and pragmatic analysis in Down $\sum 3$ syndrome (original title: Amostra de filmagem e análise da pragmática na síndrome de Down). Pró-Fono Revista de Atualização Científica, Barueri (SP), v. 19, n. 2, p. 159-166, abr.-jun. 2007. 


\section{Introduction}

Assessing language development is a complex task that requires practical and theoretical knowledge about the investigated issues. It is also important to take into account data gathering and analysis methodology, in order to achieve consistent and reliable results that mirror the subject's reality.

Owens (1996) states that it is difficult to obtain data about language development. Frequently a series of procedures is required to guarantee their objective description, validity and reliability. The author points out that the researcher's purpose and theoretical presuppositions influence the kind of data gathering procedure is used.

Data about language development are usually collected in two ways: a sample of spontaneous talk or natural observation and a structured test or experimentally manipulated situation (Owens, 1996).

The assessment of functional aspects of language, as defined the pragmatic analysis is defined (Fernandes, 1996) allows the speech-andlanguage pathologist to determine when and how the child used his/hers communicative abilities. Several methods, criteria and techniques have been used to collect and analyze data about the use of language by children.

Since the decade of 1980 many protocols, questionnaires and scales for observing the child's communicative attitude have been proposed (Baixauli-Fortea et al, 2004). Adams (2002) produced a review about the types of pragmatic assessment and described the available protocols, such as: a developmentally ordained list of emerging of different communicative intents; a comprehensive checklist of verification of pragmatic behavior, the Children Communicative Checklist; the assessment of language pragmatic knowledge and the assessment of specific details based on observation analysis. The author observes that among these assessment protocols and methods some are validated and reliable and others aren't. This way, the future of pragmatic evaluation may be not in the multiplication of coding sets but in allowing the research that is now being produced to become more accessible and to guarantee their validation and reliability by the use of appropriate statistical methods.

Owens (1996) comments that electronic methods are essential to the microanalysis. The videotape recording, although more intrusive, is better than just the audiotape recording because it allows the observation of the verbal and non verbal elements of the situation. Iverson et al (2003), studying the gestual communication of children with Down syndrome, opted to use the videotaped recording of a spontaneous situation to later transcribe all the gestures and intelligible words produced by the subjects. The authors used 30 minutes recordings in this study.

Analyzing the research about specific populations as children with Down syndrome it can be observed that many different research methods are used to assess the functional use of language. Laws and Bishop (2004a) used as a procedure to obtain data about a population that included children with Down syndrome a checklist that could be answered by children's parents or teachers. Laws and Bishop (2004b) and Andrade(2006) state that children with Down syndrome, among other deficits, present language disorder in varying degrees and with different profiles of week and unaffected points. The gesture, as a non-linguistic element, is used to communication and serves as a transition to spoken language (Capone and McGregor, 2004; Andrade, 2006; Flabiano and Limongi, 2006).

Considering the assessment of the communicative profile of individuals with diagnostics within the autistic spectrum Fernandes (2003) used the videotapes of a specific situation and a specific protocol. This situation included objects as a toy with movement, a transparent recipient difficult to open, books, bubbles, balloons, food items the children liked and disliked. The duration of the child-adult interaction wasn't mentioned. Cardoso and Fernandes (2003) also studied children of the autistic spectrum with the purpose to verify the children's performance and evolution referring to the use of interpersonal and non-interpersonal communicative functions. To do it they used games and toys, videotape recorder, tapes and protocols. The communicative situations were determined and the communicative contexts varied according to the individual and group activities proposed by the adult or chosen by the subjects. In what refers to the time of videotaping, 15 and 30 minutes of interaction were recorded to posterior analysis.

Andrade (2002) conducted a research that aimed to verify if two groups of children, with and without genetic antecedents to stuttering were different in other aspects of language development, including pragmatics. To assess pragmatics the sample was filmed and analyzed according to the pragmatic test proposed by 
Fernandes (2004).

Muñoz-Céspedes and Melle (2004) report the assessment of pragmatic abilities in individuals with brain damage (BD). The authors suggest the use of a filmed sample that allows a detailed and precise analysis of language and is also useful to document the patient's improvements. The authors also mention that the interest in the study about pragmatic competence in patients with $\mathrm{BD}$ by researchers from different fields has increased the number of assessment tests and protocols.

Crespo-Eguílaz et al (2003) assessed language of dysphasic children. The authors chose the Children's Communication Checklist to assess the pragmatic aspects of language.

As there are different gathering methods, there are also many aspects that interfere with the obtained data (Owens, 1996). Considering the context, including linguistic and non-linguistic elements, is essential when analyzing pragmatics. Any sound or gestured interpreted by the adult is considered as language (Fernandes, 1996). Already in 1978 Kreckel commented on the analysis of filmed social interactions. The author referred that this kind of analysis provides greater detailing of behavior. His study reports that the presence of a videotaping camera may cause behavior distortions, eliminating inadequate behavior and increasing the adequate ones. But the author emphasizes that only the behaviors that are really a part of the individual's repertoire can be increased or avoided. That is, a person can't produce behaviors that aren't in his/her repertoire.

The pragmatic analysis demands the consideration of context. And considering it, the filmed data gathering seems to be the most adequate method because it allows the analysis of all pragmatic aspects of an individual's language.

Determining standard assessment criteria to data analysis is important to obtaining consistent results. Besides considering the communicative act as the smallest unit of analysis - starting when the adult-child, child-adult or child-object interaction starts and ends when there is a change in attention focus or turn (Fernandes, 1996) - it is important to determine the size of the sample to be used in the analysis. Frequently 30 minutes data recordings are used (Fernandes, 2004). Aiming to obtain the larger amount of data in the shortest possible time, without jeopardizing the quality and effectiveness of data, our objective is to identify the moment and the duration of filmed sample that are more useful to the pragmatic analysis of the communication of children with Down syndrome in interaction situations.

\section{Method}

The present research was approved by the Research and Ethics Committee of the Hospital das Clínicas of the School of Medicine - University of Sao Paulo (FMUSP) with protocol number 838/05 and an adult responsible for each child signed the consent form.

Participants were 25 children with Down syndrome, chronological age between two and seven years, 15 boys and 10 girls. All subjects were attending speech-and-language therapy at the Research laboratory of speech-and-language pathology in syndromes and motor-sensorial disorders of the Physiotherapy, Speech and language pathology and occupational therapy department of FMUSP.

To collect data video VHS cameras and tapes were used to record interaction between each child and his/her speech and language therapist in play situations. The material included a box of toys with a small doll, a plastic box with a piece of cloth and a "lego" part, a basket, kitchen items miniatures (pans, plates, glasses, knives, forks, spoons, jar), animal miniatures (cat, horse, chicken, lion), food miniatures (eggs, cucumber, banana, cookie, apple), a ball, a toy truck, telephone, wood block (several shapes and colors). To the transcription of data the protocol of Functional Communicative Profile (Fernandes, 2004) was used.

Each child was filmed during 30 minutes interacting with his/her language therapist, playing with the material previously determined by the researcher. After the recording, the transcription identified: number of communicative acts, number of communicative acts per minute, communicative mean used in each communicative act (gestual, vocal or verbal) and communicative function of each communicative act produced by adult and child during the 30 minutes. During the transcription the beginning and end of the first, medium and last 15 minutes of interaction were marked. The interactivity of each communicative act was considered to the analysis of the communicative functions. This way, the communicative acts were divided in more interactive communicative acts and less interactive communicative acts, according to the classification proposed by Fernandes (2005).

After the data were registered, the analysis considered the values obtained in the total 30 minutes and the ones referring to the initial 15 minutes, the medium 15 minutes (starting after the first five minutes) and the final 15 minutes of interaction between child and therapist; afterwards 
these data were compared. The data related to 30 and 15 minutes were called "time" and the ones related to initial, medium and final were called "moments". An statistical analysis, using the Fiedman and the Wilcoxon tests and the confidence interval, with significance level of $0.05(5 \%)$, was made to verify the significance of data.

\section{Results}

It can be observed in Table 1 to 5 and in Table 7 that there were no significant differences in the results obtained in the different times and moments of analysis. Table 6 refers to the vocal mean used by the subjects and it shows a significant difference between moments. The box 1 shows only the $\mathrm{p}$ values of all two-by-two comparisons of the moments. It can be observed that the difference between the moments occurs between the initial and the medium 15 minutes.

It can be observed in Tables 8 to 11 and 13 to 14 that there were no significant differences between the results obtained from the therapists in the different times and moments of analysis. Only in Table 12 that refers to the verbal communicative mean, it can be observed a significant difference between moments. This way, box 2 shows only the p-values of all two-by-two comparisons of the moments. Is can be verified exactly where if the difference between the moments.

It can than be verified that the final 15 minutes are different from the other segments and the 30 minutes data are different from the initial 15 minutes.

Table 1 - Proportion of communicative acts produced by the subjects

\begin{tabular}{lcccc}
\hline \multirow{2}{*}{ C.Children } & \multicolumn{4}{c}{ COMMUNICATIVE ACTS } \\
\cline { 2 - 5 } & $30^{\prime}$ & Initial 15' & Medium 15' & Final 15' \\
\hline Average & 41.96 & 42.06 & 42.14 & 41.84 \\
\hline Mean & 41.80 & 42.70 & 42.70 & 43.20 \\
\hline Standard Deviation & 5.4 & 5.5 & 5.2 & 6.4 \\
\hline Q1 & 40.0 & 39.6 & 38.4 & 38.5 \\
\hline Q3 & 44.9 & 45.4 & 44.6 & 44.8 \\
\hline $\mathrm{N}$ & 25 & 25 & 25 & 25 \\
\hline Inferior threshold & 39.84 & 39.90 & 40.09 & 39.31 \\
\hline Superior threshold & 44.09 & 44.22 & 44.19 & 44.37 \\
\hline p-value & & \multicolumn{5}{c}{0.811} \\
\hline
\end{tabular}

Table 2 - Proportion of less-interactive communicative functions produced by the subjects

\begin{tabular}{lcccc}
\hline \multicolumn{1}{c}{ Children } & \multicolumn{4}{c}{ LESS INTERACTIVE FUNCTIONS } \\
\hline & $30^{\prime}$ & Initial 15' & Medium 15' & Final 15' \\
\hline Average & 29.32 & 30.37 & 30.61 & 28.67 \\
\hline Mean & 25.30 & 23.70 & 25.00 & 26.10 \\
\hline Standard Deviation & 11.9 & 14.3 & 14.9 & 11.1 \\
\hline Q1 & 21.1 & 21.5 & 19.2 & 22.1 \\
\hline Q3 & 35.5 & 41.2 & 38.9 & 31.3 \\
\hline $\mathrm{N}$ & 25 & 25 & 25 & 25 \\
\hline Inferior threshold & 24.65 & 24.77 & 24.76 & 24.32 \\
\hline Superior threshold & 33.98 & 35.97 & 36.45 \\
\hline p-value & & \multicolumn{5}{c}{0.536 .02} \\
\hline
\end{tabular}


Table 3 - Proportion of more-interactive communicative functions produced by the subjects

\begin{tabular}{lcccc}
\hline \multirow{2}{*}{ Children } & \multicolumn{4}{c}{ MORE INTERACTIVE FUNCTIONS } \\
\cline { 2 - 5 } & $30^{\prime}$ & Initial 15' & Medium 15' & Final 15' \\
\hline Average & 70.72 & 69.64 & 69.38 & 71.33 \\
\hline Mean & 74.70 & 76.30 & 75.00 & 73.90 \\
\hline Standard Deviation & 11.9 & 14.3 & 14.9 & 11.1 \\
\hline Q1 & 64.5 & 58.8 & 61.1 & 68.8 \\
\hline Q3 & 78.9 & 78.5 & 80.8 & 77.9 \\
\hline N & 25 & 25 & 25 & 25 \\
\hline Inferior threshold & 66.06 & 64.04 & 63.52 & 66.98 \\
\hline Superior threshold & 75.37 & 75.23 & 75.23 & 75.68 \\
\hline p-value & & \multicolumn{5}{c}{0.536} \\
\hline
\end{tabular}

Table 4 - Number of communicative acts produced by the subjects per minute

\begin{tabular}{lcccc}
\hline \multicolumn{1}{c}{ Children } & \multicolumn{5}{c}{ COMMUNICATIVE ACTS PER MINUTE } \\
\hline & $30^{\prime}$ & Initial 15' & Medium 15' & Final 15' \\
\hline Average & 6.40 & 4.96 & 5.11 & 4.91 \\
\hline Mean & 4.90 & 4.50 & 4.90 & 4.60 \\
\hline Standard Deviation & 7.3 & 1.6 & 1.5 & 1.4 \\
\hline Q1 & 3.9 & 3.8 & 3.9 & 3.9 \\
\hline Q3 & 6.3 & 6.2 & 6.3 & 6.0 \\
\hline $\mathrm{N}$ & 25 & 25 & 25 & 25 \\
\hline Inferior threshold & 3.52 & 4.32 & 4.51 & 4.37 \\
\hline Superior threshold & 9.28 & 5.59 & 5.71 & 5.45 \\
\hline p-value & & & 0.505 & \\
\hline
\end{tabular}

Table 5 - Proportion of verbal communicative acts produced by the subjects

\begin{tabular}{lcccc}
\hline \multirow{2}{*}{ Children } & \multicolumn{4}{c}{ VERBAL COMMUNICATIVE MEAN } \\
\cline { 2 - 5 } & $30^{\prime}$ & Initial 15' & Medium 15' & Final 15' \\
\hline Average & 23.91 & 22.76 & 22.89 & 24.85 \\
\hline Mean & 6.10 & 5.10 & 5.10 & 7.40 \\
\hline Standard Deviation & 27.9 & 26.7 & 26.5 & 28.9 \\
\hline Q1 & 0.9 & 1.4 & 1.8 & 0.0 \\
\hline Q3 & 48.5 & 50.8 & 51.0 & 49.5 \\
\hline N & 25 & 25 & 25 & 25 \\
\hline Inferior threshold & 12.99 & 12.28 & 12.51 & 13.53 \\
\hline Superior threshold & 34.84 & 33.24 & 33.27 & 36.18 \\
\hline p-value & & & 0.824 & \\
\hline
\end{tabular}


Table 6 - Proportion of vocal communicative acts produced by the subjects

\begin{tabular}{lcccc}
\hline \multirow{2}{*}{ Children } & \multicolumn{5}{c}{ VOCAL COMMUNICATIVE MEAN } \\
\cline { 2 - 5 } & $30^{\prime}$ & Initial 15' & Medium 15' & Final 15' \\
\hline Average & 26.60 & 24.08 & 27.84 & 28.86 \\
\hline Mean & 28.70 & 26.90 & 31.70 & 28.90 \\
\hline Standard Deviation & 17.3 & 17.3 & 17.5 & 18.9 \\
\hline Q1 & 9.0 & 9.8 & 12.4 & 9.3 \\
\hline Q3 & 37.6 & 32.3 & 39.8 & 40.4 \\
\hline $\mathrm{N}$ & 25 & 25 & 25 & 25 \\
\hline Inferior threshold & 19.82 & 17.29 & 20.99 & 21.43 \\
\hline Superior threshold & 33.38 & 30.86 & 34.68 & 36.28 \\
\hline p-value & \multicolumn{5}{c}{$0.014^{*}$} \\
\hline * statistically significant p-value & & & \\
Box 1 - p-values & & $30^{\prime}$ & Initial 15' & Medium 15' \\
\hline Vocal communicative mean & 0.115 & \\
\hline \multicolumn{5}{c}{ Initial 15' } \\
Medium 15' & $0.090 \#$ \\
\hline Final 15' & $0.087 \#$ \\
\hline
\end{tabular}

* statistically significant p-value

\# p-value near the significance limit

Table 7 - Proportion of gestual communicative acts produced by the subjects

\begin{tabular}{lcccc}
\hline \multirow{2}{*}{ Children } & \multicolumn{4}{c}{ GESTUAL COMMUNICATIVE MEAN } \\
\cline { 2 - 5 } & $30^{\prime}$ & Initial 15' & Medium 15' & Final 15' \\
\hline Average & 72.19 & 72.38 & 68.99 & 71.89 \\
\hline Mean & 79.40 & 83.60 & 70.40 & 74.70 \\
\hline Standard Deviation & 21.7 & 23.2 & 23.7 & 22.1 \\
\hline Q1 & 56.4 & 50.0 & 46.0 & 62.2 \\
\hline Q3 & 90.4 & 93.5 & 90.2 & 87.5 \\
\hline $\mathrm{N}$ & 25 & 25 & 25 & 25 \\
\hline Inferior threshold & 63.67 & 63.28 & 59.69 & 63.21 \\
\hline Superior threshold & 80.72 & 81.48 & 78.29 & 80.57 \\
\hline p-value & & \multicolumn{5}{c}{0.141} \\
\hline
\end{tabular}

Table 8 - Proportion of communicative acts produced by the therapists

\begin{tabular}{lcccc}
\hline \multirow{2}{*}{ Adults } & \multicolumn{4}{c}{ COMMUNICATIVE ACTS } \\
\cline { 2 - 5 } & $30^{\prime}$ & Initial 15' & Medium 15' & Final 15' \\
\hline Average & 58.04 & 57.94 & 57.86 & 58.17 \\
\hline Mean & 58.20 & 57.30 & 57.30 & 56.80 \\
\hline Standard Deviation & 5.4 & 5.5 & 5.2 & 6.5 \\
\hline Q1 & 55.1 & 54.6 & 55.4 & 55.2 \\
\hline Q3 & 60.0 & 60.4 & 61.6 & 61.5 \\
\hline $\mathrm{N}$ & 25 & 25 & 25 & 25 \\
\hline Inferior threshold & 55.91 & 55.78 & 55.81 & 55.64 \\
\hline Superior threshold & 60.16 & 60.10 & 59.91 \\
\hline p-value & & \multicolumn{5}{c}{0.811} \\
\hline
\end{tabular}


Table 9 - Proportion of less-interactive communicative functions produced by the therapists

\begin{tabular}{lcccc}
\hline \multirow{2}{*}{ Adults } & \multicolumn{4}{c}{ LESS INTERACTIVE FUNCTIONS } \\
\cline { 2 - 5 } & $30^{\prime}$ & Initial 15' & Medium 15' & Final 15' \\
\hline Average & 2.48 & 2.89 & 2.85 & 2.22 \\
\hline Mean & 1.70 & 2.40 & 1.40 & 1.45 \\
\hline Standard Deviation & 2.2 & 3.0 & 3.7 & 2.0 \\
\hline Q1 & 1.1 & 0.0 & 0.7 & 1.0 \\
\hline Q3 & 3.2 & 4.6 & 4.2 & 3.2 \\
\hline $\mathrm{N}$ & 25 & 25 & 25 & 25 \\
\hline Inferior threshold & 1.61 & 1.72 & 1.40 & 1.45 \\
\hline Superior threshold & 3.35 & 4.06 & 4.30 \\
\hline p-value & & \multicolumn{5}{c}{0.236} \\
\hline
\end{tabular}

Table 10 - Proportion of more-interactive communicative functions produced by the therapists

\begin{tabular}{lcccc}
\hline \multirow{2}{*}{ Adults } & \multicolumn{4}{c}{ MORE INTERACTIVE FUNCTIONS } \\
\cline { 2 - 5 } & $30^{\prime}$ & Initial 15' & Medium 15' & Final 15' \\
\hline Average & 97.52 & 97.12 & 97.18 & 97.87 \\
\hline Mean & 98.30 & 97.60 & 98.60 & 98.60 \\
\hline Standard Deviation & 2.2 & 3.0 & 3.7 & 2.0 \\
\hline Q1 & 96.8 & 95.4 & 95.8 & 96.9 \\
\hline Q3 & 98.9 & 100.0 & 100.0 & 99.1 \\
\hline $\mathrm{N}$ & 25 & 25 & 25 & 25 \\
\hline Inferior threshold & 96.65 & 95.94 & 95.72 & 97.09 \\
\hline Superior threshold & 98.39 & 98.29 & 98.63 & 98.65 \\
\hline p-value & \multicolumn{5}{c}{0.255} \\
\hline
\end{tabular}

Table 11 - Number of communicative acts produced by the therapists per minute

\begin{tabular}{lcccc}
\hline \multirow{2}{*}{ Adults } & \multicolumn{4}{c}{ COMMUNICATIVE ACTS PER MINUTE } \\
\cline { 2 - 5 } & $30^{\prime}$ & Initial 15' & Medium 15' & Final 15' \\
\hline Average & 6.69 & 6.66 & 6.92 & 6.74 \\
\hline Mean & 6.50 & 6.00 & 6.80 & 6.40 \\
\hline Standard Deviation & 1.2 & 1.4 & 1.5 & 1.3 \\
\hline Q1 & 5.8 & 5.7 & 5.8 & 5.7 \\
\hline Q3 & 7.3 & 7.9 & 7.9 & 7.9 \\
\hline $\mathrm{N}$ & 25 & 25 & 25 & 25 \\
\hline Inferior threshold & 6.23 & 6.10 & 6.35 & 6.24 \\
\hline Superior threshold & 7.15 & 7.22 & 7.49 & 7.24 \\
\hline p-value & & \multicolumn{5}{c}{0.714} \\
\hline
\end{tabular}


Table 12 - Proportion of verbal communicative acts produced by the therapists

\begin{tabular}{|c|c|c|c|c|}
\hline \multirow{2}{*}{ Adults } & \multicolumn{4}{|c|}{ VERBAL COMMUNICATIVE MEAN } \\
\hline & $30^{\prime}$ & Initial $15^{\prime}$ & Medium 15' & Final 15' \\
\hline Average & 94.42 & 95.24 & 95.08 & 93.09 \\
\hline Mean & 95.40 & 95.80 & 95.30 & 93.75 \\
\hline Standard Deviation & 3.5 & 3.7 & 3.9 & 4.7 \\
\hline Q1 & 93.6 & 93.9 & 93.5 & 91.4 \\
\hline Q3 & 97.0 & 98.1 & 98.3 & 96.0 \\
\hline $\mathrm{N}$ & 25 & 25 & 25 & 25 \\
\hline Inferior threshold & 93.04 & 93.77 & 93.54 & 91.25 \\
\hline Superior threshold & 95.81 & 96.70 & 96.62 & 94.92 \\
\hline p-value & \multicolumn{4}{|c|}{$<0.001 *$} \\
\hline $\begin{array}{l}\text { * statistically signific } \\
\text { Box } 2-\text { p-values }\end{array}$ & $\overline{\text { p-value }}$ & & & \\
\hline \multicolumn{2}{|c|}{ Verbal communicative mean } & $30^{\prime}$ & Initial 15' & Medium 15' \\
\hline \multicolumn{2}{|l|}{ Initial 15' } & $0.023^{*}$ & & \\
\hline \multicolumn{2}{|l|}{ Medium 15' } & 0.214 & 0.101 & \\
\hline \multicolumn{2}{|l|}{ Final 15' } & $0.009 *$ & $0.031^{*}$ & $0.035^{*}$ \\
\hline
\end{tabular}

Table 13 - Proportion of vocal communicative acts produced by the therapists

\begin{tabular}{lcccc}
\hline \multirow{2}{*}{ Adults } & \multicolumn{4}{c}{ VOCAL COMMUNICATIVE MEAN } \\
\cline { 2 - 5 } & $30^{\prime}$ & Initial 15' & Medium 15' & Final 15' \\
\hline Average & 5.82 & 1.98 & 2.06 & 2.69 \\
\hline Mean & 1.80 & 1.40 & 1.50 & 2.40 \\
\hline Standard Deviation & 17.4 & 1.9 & 2.3 & 3.5 \\
\hline $\mathrm{Q} 1$ & 1.1 & 0.0 & 0.0 & 1.0 \\
\hline $\mathrm{Q} 3$ & 3.2 & 3.5 & 2.9 & 3.0 \\
\hline $\mathrm{N}$ & 25 & 25 & 25 & 25 \\
\hline Inferior threshold & -1.01 & 1.26 & 1.16 & 1.30 \\
\hline Superior threshold & 12.65 & 2.71 & 2.96 & 4.08 \\
\hline p-value & \multicolumn{5}{c}{0.977} \\
\hline
\end{tabular}

Table 14 - Proportion of gestual communicative acts produced by the therapists

\begin{tabular}{lcccc}
\hline \multirow{2}{*}{ Adults } & \multicolumn{4}{c}{ GESTUAL COMMUNICATIVE MEAN } \\
\cline { 2 - 5 } & $30^{\prime}$ & Initial 15' & Medium 15' & Final 15' \\
\hline Average & 30.11 & 27.88 & 27.55 & 32.38 \\
\hline Mean & 31.40 & 26.10 & 26.30 & 34.60 \\
\hline Standard Deviation & 13.6 & 13.5 & 13.0 & 15.7 \\
\hline Q1 & 20.0 & 17.5 & 18.0 & 17.2 \\
\hline Q3 & 41.4 & 32.4 & 38.3 & 42.9 \\
\hline $\mathrm{N}$ & 25 & 25 & 25 & 25 \\
\hline Inferior threshold & 24.78 & 22.60 & 22.47 & 26.22 \\
\hline Superior threshold & 35.45 & 33.17 & 32.63 & 38.55 \\
\hline
\end{tabular}




\section{Discussion}

The purpose of this study was to identify the best amount of time and specific moment to perform the pragmatic analysis of the communication of children with Down syndrome. The aim is to obtain the largest amount of data in the shortest time possible without jeopardizing their quality and reliability.

Data was obtained during spontaneous play situations, as it's been done in other studies (Andrade, 2006, Flabiano and Limongi, 2006). It is also consistent with the literature that proposes to reinforce the adult-child relationship (Owens, 1996).

The interaction between child and therapist was videotaped allowing the detailed analysis of the communicative behavior expressed by the child as well as the adult. This procedure of data gathering and recording was proposed by Kreckel (1978) in his study. Authors as Andrade (2002), Fernandes (2003), Cardoso and Fernandes (2003) and Muñoz-Céspedes also used video cameras to record samples to the assessment of language functions in different populations.

Crespo-Eguílaz et al. (2003) and Laws and Bishop (2004) used questionnaires and checklists in their research. Important data as communicative context and non-linguistic elements (as gestures and face and body expressions) that should be considered as language in the functional study of communication (Fernandes, 1996) may be lost by the use of checklists and questionnaires.

Considering that the population studied present a delay in the language acquisition and development process (Law and Bishop, 2004b) and that many of them do not use the verbal mean of communication, the use of the vocal mean is extremely important to the language development process (Andrade, 2006; Flabiano and Limongi, 2006). This way, considering just the item "vocal communicative mean", it can be stated that the time and moment of better performance were the final 15 minutes.

The analysis of the therapist's pragmatic performance while interacting with the child has shown that the only significant difference is also related to the communicative means. The values obtained for the use of the verbal communicative mean during the final 15 minutes were different of the other time and moments. The final 15 minutes constitute the moment with the smallest average proportion of use of the verbal mean by the adult (93.09\%).
Considering individual differences is essential when assessing the functional use of language. The behavior must be considered, as well as the communicative context that includes linguistic and non-linguistic components, as suggested by Fernandes (1996). The assessment method proposed by Fernandes (2004) includes items that constitute the individual communicative profile. Considering that there was no significant difference of time and moment in most of the analyzed data, any of them can be used to analyze the communicative profile of the studied population.

\section{Conclusion}

The aim of this study was to verify the better time and moment to collect data about the pragmatic aspects of the communication of children with Down syndrome. No significant differences were found in the samples with 15 or 30 minutes of duration. It is important to note that the statistical analysis was based on the average values obtained in this specific group of subjects. Therefore, these results are useful to significant samplings and group data for research use, where average values are used. It means that videotaped samples of either 15 or 30 minutes, of the beginning, the middle or the end of the footage can be used to analyze the communicative profile of individuals with Down syndrome, without any risk to the quality and reliability of the results.

However, it can be that for any specific subject there are significant differences on different times and different moments. This way, when considering language and communication development within the language therapy process, the individual analysis is essential to the determination of intervention proposals based on specific characteristics of each individual.

It is important to stress that if in one hand the analysis of filmed samples allows the reproducibility and reliability of results, on the other hand it involves a limited picture of the child's communicative abilities, once the communicative context and motivational factors are limited and the interlocutors are trained specialists. It leads to the conclusion of how important are studies that assess the complexity of both ways of data gathering, since interviews and questionnaires may provide data about the child's communication in different contexts, with different states of mind and with different communicative partners. 


\section{Referências Bibliográficas}

ADAMS, C. Practitioner review: the assessment of language pragmatics. J. child psychol. psychiat., Malden, v. 43 , n. 8 , p. 973-987, nov. 2002.

ANDRADE, C. R. F. História natural da gagueira - estudo III: vocabulário, fonologia e pragmática. Pró-fono $R$. Atual. Cient., Barueri (SP), v. 14, n. 3, p. 371-382, set.dez. 2002.

ANDRADE, R. V. A emergência da expressão comunicativa na criança com síndrome de Down. 2006. 206 f. Tese (Doutorado em Fisiopatologia Experimental) - Faculdade de Medicina, Universidade de São Paulo, São Paulo.

BAIXAULI-FORTEA, I.; ROSELLÓ, B.; MIRANDACASA, A. Evaluación de las dificultades pragmáticas: estudo de caso. R. Neurol., Barcelona, v. 38, supl. 1, p. 69-79, jan.-jun. 2004.

BERGLUND, E.; ERIKSSON, M.; JOHANSSON, I. Parental Reports of spoken language skills in children with Down Syndrome. J. Speech Lang. Hear. Res., Mariland, v. 44, n. 1, p. 179-191, fev. 2001.

CARDOSO, C.; FERNANDES, F. D. M. Uso de funções comunicativas interpessoais e não interpessoais em crianças do espectro autístico. Pró-fono R. Atual. Cient., Barueri (SP), v. 15, n. 3, p. 279-286, set.-dez. 2003.

CAPONE, N. C.; MCGREGOR, K. K. Gesture development: a review for clinical and reaserch practices. J. Speech Lang. Hear. Res., Mariland, v. 47, n. 1, p. 173-186, fev. 2004.

CRESPO-EQUÍllaZ, N.; NARBONA, J. Perfiles clínicos evolutivos y transiciones em el espectro del trastorno específico del desarrollo del lenguaje. R. Neurol., Barcelona, v. 36, supl. 1, p. 29-35, jan.-jun. 2003.

FERNANDES, F. D. M. Autismo infantil: repensando o enfoque fonoaudiológico - aspectos funcionais da comunicação. São Paulo: Lovise, 1996.

FERNANDES, F. D. M. Perfil comunicativo, desempenho sócio-cognitivo, vocabulário e meta-representação em crianças com transtornos do espectro autístico. Pró-fono R. Atual. Cient., Barueri (SP), v. 15, n. 3, p. 267-278, set.-dez. 2003.
FERNANDES, F. D. M. Pragmática. In: ANDRADE C. R. F.; BEFI-LOPES, D. M.; FERNANDES, F. D. M.; WERTZNER, H. $A B F W$ : teste de linguagem infantil nas áreas de fonologia, vocabulário, fluência e pragmática. Barueri (SP): Pró-Fono, 2004. cap. 4, p. 83-97.

FERNANDES, F. D. M. Resultados de terapia fonoaudiológica com adolescentes com diagnóstico incluído no espectro autístico. Pro-fono R. Atual. Cient., Barueri (SP), v. 17, n. 1, p. 67-76, jan-abr. 2005.

FLABIANO, F. C.; LIMONGI, S. C. O. Relação entre gestos e linguagem oral em um par de gêmeos com síndrome de Down. R. Soc. Bras. Fonoaudiol., São Paulo, v. 11 , n. 2, abr. 2006.

IVERSON, J. M.; LONGOBARDI, E.; CASELLI, M. C. Relationship between gestures and words in children with Down'syndroeme and typicallly developing children in the early stages of communicative development. Int. J. Lang. Commun. Dis., United Kingdon, v. 38, n. 2, p. 179-197, apr-jun. 2003.

KRECKEL, M. Comunicative acts: a semiological approach to the empirical analysis of filmed interaction. Semiotica, Cambridge, v. 24, n. 1 e n. 2, p. 85-111, janfeb. 1978.

LAWS, G.; BISHOP, V. M. Pragmatic language impairment and social deficits in Williams syndrome: a comparison with Down's syndrome and specific language impairment. Int. J. Lang. Commun. Dis., United Kingdon, v. 39, n. 1, p. 45-64, jan-mar. 2004a.

LAWS, G.; BISHOP, V. M. Verbal deficits in Down syndrome and specific language impairment: a comparison. Int. J. Lang. Commun. Dis., United Kingdon, v. 39, n. 4, p. 423-451, oct-dec. 2004b.

MUÑOZ-CÉPEDES, J. M.; MELLE, N. Alteraciones de la pragmática de la comunicación después de um traumatismo craneoencefálico. R. Neurol., Barcelona, v. 38, n. 9, p. 856-859, maio 2004.

OWENS, R. Language research and analysis. In: OWES, R. Language and development. [S.1.: s.n.], Needhan Heigth: Allyn \& Bacon, 1996. p. 429-443. 